\title{
PENETAPAN TEMPAT KHUSUS PARKIR DI KAWASAN OBJEK WISATA KULINER CIMANUK INDRAMAYU BERDASARKAN PERATURAN DAERAH NOMOR 16 TAHUN 2017 PENYELENGGARAAN PERPARKIRAN DI KABUPATEN INDRAMAYU
}

\author{
Syamsul Bahri Siregar \\ Suchi Susanti Dwi Sonjaya \\ Universitas Wiralodra \\ Email : syamsulbahrisiregarunwir@gmail.com, \\ suchisonjaya@gmail.com
}

\begin{abstract}
The increasing use of private transportation, now more and more public places that provide vehicle storage facilities in their area. This vehicle storage is better known as parking by the community. In Article 1 No. 14 of the Regional Regulation of Indramayu Regency Number 16 of 2017 concerning Parking Management which states that parking can be interpreted as a state of stopping or not moving for a while and being abandoned by the driver. The existence of a parking lot is very helpful for the community, especially for those who have vehicles, you can imagine if there is no parking space. In the concept of this scientific paper using the normative juridical research method. As well as using data collection techniques carried out using descriptive analysis techniques, with secondary data sources, which include primary legal materials such as laws and regulations relating to the Regional Regulation of Indramayu Regency Number 16 of 2017 concerning Parking Management. The purpose of this study is to find out where special parking spaces can be established in the Cimanuk Indramayu culinary tourism object based on Regional Regulation Number 16 of 2017 concerning Parking Implementation and to find out the management of parking special areas in Indramayu based on Regional Regulation of Indramayu Regency Number 16 of 2017 concerning Parking Implementation. The results of this study indicate that in the implementation of Parking Management in Indramayu Regency, it has been regulated in the Regional Regulation of Indramayu Regency Number 16 of 2017 concerning Parking Management and has been in accordance with applicable regulations. But in its implementation, this is not like that because in implementation, the parking lot is a utility, only useful for local governments for regional income but for the community it is very burdensome.
\end{abstract}

Keywords: Tourist attraction, Parking area, Parking organizers.

\section{PENDAHULUAN}

Perkembangan serta pertumbuhan ekonomi suatu kota diikuti dengan semakin meningkatnya kebutuhan masyarakat di dalamnya, kebutuhan tersebut meliputi kebutuhan pokok maupun kebutuhan tambahan. Salah satu kebutuhan tambahan masyarakat adalah 
kebutuhan akan penggunaan alat transportasi yang semakin meningkat terutama terhadap kebutuhan alat transportasi pribadi. Meningkatnya kebutuhan akan transportasi pribadi ini dikarenakan selain mempermudah masyarakat dalam melakukan aktifitasnya sehari-hari juga dapat mengefiensi waktu serta tenaga dalam menunjang aktifitas tersebut.

Meningkatnya penggunaan transportasi pribadi sekarang ini semakin banyak tempattempat umum yang memberikan fasilitas penitipan kendaraan di wilayahnya. Penitipan kendaraan ini lebih dikenal dengan istilah parkir oleh masyarakat. Parkir telah menjadi salah satu hal yang krusial dalam lalu lintas jalan, terutama di kota-kota besar. Keberadaan tempat parkir sangat membantu masyarakat khususnya bagi mereka yang memiliki kendaraan.

Hal inilah yang membuat lahan parkir dapat dijadikan suatu bisnis yang sangat menggiurkan karena setiap orang memiliki kendaraan pasti memerlukan tempat parkir ditambah lagi peningkatan jumlah kendaraan di kota-kota besar Indonesia dari tahun ke tahun selalu bertambah termasuk salah satunya di Kabupaten Indramayu.

Pada Pasal 8 ayat (2) Peraturan Daerah Kabupaten Indramayu Nomor 16 Tahun 2017 Tentang Penyelenggaraan Perparkiran yang menyatakan bahwa penyelengaraan tempat parkir yang dilaksanakan pemerintah daerah terdiri dari tempat parkir di tepi jalan umum, tempat khusus parkir dan parkir tidak tetap.

Kawasan kuliner Cimanuk merupakan salah satu objek wisata kuliner yang menjadi kegemaran semua kalangan masyarakat Indramayu. Kawasan kuliner Cimanuk selain sebagai fasilitas kuliner, juga menyediakan fasilitas untuk kegiatan-kegiatan bermanfaat seperti kegiatan seni dan budaya, pameran, kegiatan musik untuk masyarakat. Adanya kawasan kuliner Cimanuk memberikan peluang kerja untuk masyarakat Indramayu, bertujuan untuk mengurangi pengangguran seperti berdagang dan membuka lahan perparkiran. Atas dasar itu Pemerintah Daerah Indramayu telah menetapkan tempat khusus parkir di kawasan kuliner Cimanuk.

Disisi lain Penetapan tempat khusus parkir di kawasan kuliner Cimanuk Indramayu menimbulkan ketidaknyamanan pengunjung salah satunya yakni tidak dapat menghabiskan waktu yang lama dikarenakan adanya sistem parkir otomatis mengakibatkan sebagian masyarakat khususnya dikalangan masyarakat yang ingin menikmati sore di kawasan objek wisata kuliner cimanuk, dengan adanya tarif parkir yang hitungannya bertambah setiap jam membuat kurangnya minat sebagian besar masyarakat untuk menghabiskan waktu di kawasan tersebut. Dengan berkurangnya sebagian masyarakat yang tidak setuju dengan 


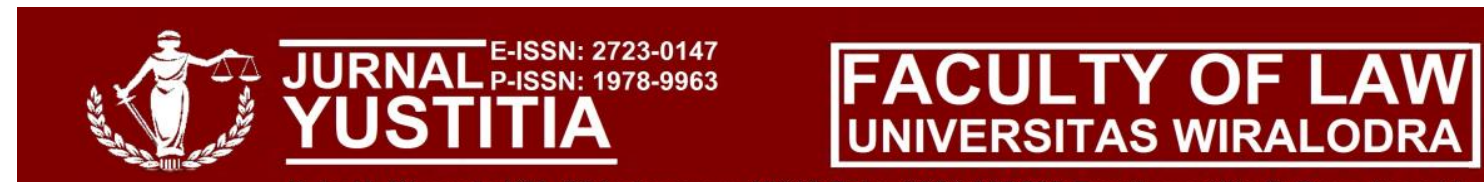

JI. Ir. H. Djuanda KM. 03 Indramayu 45213 Telp. 0234-275599 Email: yustitia.fh@unwir.ac.id

penetapan tarif parkir khusus ini, maka pembeli tetap dari penjual-penjual makanan tersebut akan menurun dan mengurangi pendapatan pedagang-pedagang di kawasan objek wisata kuliner Cimanuk.

Adanya lahan tempat parkir khusus di kawasan objek wisata kuliner Cimanuk ini menjadikan sumber dana bagi pemerintah daerah sebagai pendapatan daerah untuk meningkatkan Pendapatan Asli Daerah (PAD), namun disisi lain dengan adanya penerapan sistem tempat khusus parkir dapat merugikan pihak pedagang dan masyarakat. Dalam hal ini yang menjadikan adanya tarik ulur kepentingan pengelolaan parkir dikawasan kuliner Cimanuk tersebut.

\section{IDENTIFIKASI MASALAH}

Berdasarkan latar belakang masalah diatas maka penulis dapat mengidentifikasi permasalahan sebagai berikut:

1. Apakah Tempat Khusus Parkir Dapat Ditetapkan Di Kawasan Objek Wisata Kuliner Cimanuk Indramayu Berdasarkan Peraturan Daerah Nomor 16 Tahun 2017 Tentang Penyelenggaraan Perparkiran.

2. Bagaimana Pengelolaan Tempat Khusus Parkir Di Indramayu Berdasarkan Peraturan Daerah Kabupaten Indramayu Nomor 16 Tahun 2017 Tentang Penyelenggaraan Perparkiran.

\section{METODE}

Metode yang digunakan dalam penelitian ini adalah metode pendekatan yuridis normatif, atau penelitian hukum kepustakaan, yaitu penelitian hukum yang dilakukan dengan cara meneliti bahan pustaka atau data sekunder ${ }^{1}$. Dalam hal ini dengan mengkaji permasalahan dari segi hukum yang terdapat dalam Peraturan Daerah serta dari pustaka yang relevan dengan pokok bahasan.

\section{IV.LANDASAN TEORITIS}

Melakukan sebuah penelitian ini diperlukan adanya landasan teoritis, sebagaimana dikemukakan oleh M. Solly Lubis bahwa landasan teoritis merupakan kerangka pemikiran

\footnotetext{
1 Soerjono Soekanto dan Sri Mamudji, "Penelitian Hukum Normatif: Suatu Tinjauan Singkat”, cet. 9, Rajawali Press, Jakarta, 2006, hlm. 23.
} 
atau butir-butir pendapat, teori, asas, maupun konsep yang relevan digunakan untuk mengupas suatu kasus atau permasalahan ${ }^{2}$.

\section{A. Teori Negara Hukum}

Gagasan Negara hukum itu pertama kali dikemukakan oleh Plato dan dipertegas oleh Aristoteles. Menurut Aristoteles yang memerintah dalam negara bukanlah manusia sebenarnya, melainkan pikiran yang adil, sedangkan penguasa sebenarnya hanya memegang hukum dan keseimbangan saja ${ }^{3}$. Kesusilaan yang akan menentukan baik dan tidaknya suatu peraturan Undang-undang dan membuat undang-undang adalah sebagian dari kecakapan menjalankan pemerintahan negara ${ }^{4}$. Aristoteles juga mengatakan bahwa suatu negara yang baik ialah negara yang di perintahkan dengan konstitusi dan berkedaulatan hukum. Ada tiga unsur dari pemeritahan yang berkonstitusi yaitu pertama, pemerintahan dilaksanakan untuk kepentingan umum; kedua, pemerintahan dilaksanakan menurut hukum yang berdasarkan pada ketentuan-ketentuan umum, bukan hukum yang dibuauut secara sewenang-wenang yang menyampingkan konvensi dan konstitusi; ketiga, pemerintah berkonstitusi berarti pemerintahan yang dilaksanakan atas kehendak rakyat ${ }^{5}$.

Konsep negara hukum secara lebih jelas dikemukakan oleh Julius Stahl yang memberikan karakteristik dari suatu negara hukum, yaitu adanya perlindungan hukum terhadap hak asasi manusia, adanya pembagian kekuasaan sehingga tidak tersentralisasi pada satu orang atau satu badan saja. Pemerintahan diselenggarakan berdasarkan undang-undang dan jika pemerintah dalam menjalankan pemerintahannya melakukan pelanggaran hak asasi manusia maka harus diselesaikan melalui suatu pengadilan administrasi (Pengadilan Tata Usaha Negara) ${ }^{6}$.

\section{B. Teori Penetapan Peraturan Perundang-Undangan}

Peraturan perundang-undangan di Indonesia telah diatur dalam Undang-Undang Nomor 12 Tahun 2011 tentang Pembentukan Peraturan Perundang-Undangan. Pengertian perundang-undangan menurut para ahli sendiri sangatlah beragam. Seperti pendapat Bagir Manan, bahwa peraturan perundang-undangan adalah keputusan tertulis negara atau

\footnotetext{
M. Solly Lubis, “Filsafat Ilmu dan Penelitian”, Bandar Maju, Bandung, 1994, hlm. 80.

Rozikin Daman, "Hukum Tata Negara”, PT. Raja Grafindo Persada, Jakarta, hlm. 166.

4 Moh. Kusnardi, "Hukum Tata Negara Indonesia”, Sinar Bakti, 1987, hlm. 154.

5 Ridwan HR, "Hukum Administrasi Negara Indonesia”, PT. Raja Grafindo Persada, Jakarta, 2006, hlm. 2.

6 Stahl, Julius dalam Jimly Asshiddqie, "Konstitusi \& Konstitualisme Indonesia”, Cet. 2, Sinar Grafika, Jakarta, 2011, hlm. 125.
} 


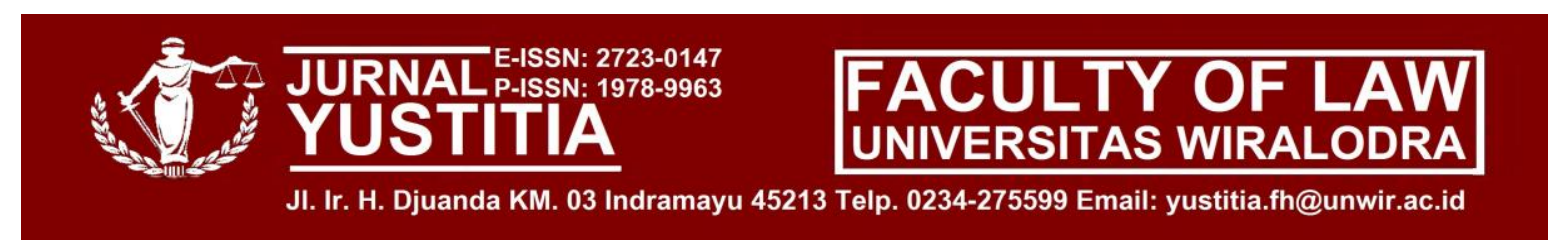

pemerintah yang berisi petunjuk atau pola tingkah laku yang bersifat dan mengikat secara umum $^{7}$. Menurut Bagir Manan yang mengutip pendapat P.J.P tentang wet in materiele zin menggambaarkan pengertian Perundang-undangan dala arti material yang esensinya antara lain sebagai berikut: ${ }^{8}$

a. Peraturan perundang-undangan berbentuk keputusan tertulis. Karena merupakan keputusan tertulis, peraturan perundang-undangan sebagai kaidah hukum tertulis.

b. Peraturan perundang-undangan dibentuk oleh pejabat atau lingkungan jabatan (badan, organ) yang mempunyai wewenang membuat "peraturan" yang berlaku atau mengikut umum.

c. Peraturan perundang-undangan bersifat mengikat umum, tidak dimaksudnya harus selalu mengikat semua orang. Mengikat umum hanya menunjukan bahwa Peraturan perundang-undangan tidak berlaku terhadap peristiwa konkret atau individu tertentu.

Tata urutan peraturan perundang-undangan sering dikaitkan dengan ajaran Hans Kelsen mengenai Stuffenbau des Rechtatau The Hierarchy of Law. Hans Kelsen berpendapat bahwa norma-norma hukum itu berjenjang-jenjang dan berlapis-lapis dalam suatu hierarki tata susunan, di mana suatu norma yang lebih rendah berlaku, bersumber, dan berdasar pada norma yang lebih tinggi, norma yang lebih tinggi berlaku, bersumber dan berdasar pada norma yang lebih tinggi lagi, dan seterusnya sampai pada suatu norma yang tidak dapat ditelusuri lebih lanjut dan bersifat hipotetis dan fiktif, yaitu Norma Dasar (Grundnorm) ${ }^{9}$.

Berdasarkan teorti Nawiasky tersebut, A. Hamid S. Attamimi membandingkannya dengan teori Kelsen dan menerapkannya pada struktur taat hukum di Indonesi. Attamimi menunjukan struktur hierarki taat hukum Indonesia dengan menggunakan teori Nawiasky. Berdasarkan teori tersebut, struktur tata hukum Indonesia adalah: ${ }^{10}$

a. Staats fundamental norm : Pancasila (Pembukaan UUD RI tahun 1945);

\footnotetext{
7 Bagir manan, “Dasar-Dasar Perundang-Undangan Indonesia”, Ind-Hill-Co, Jakarta, 1992, hlm. 18.

8 Mahendra Kurniawan, dkk, "Pedoman Naskah Akademik PERDA Partisipatif", Cet. Ke I, Kreasi Total Media, Yogyakarta, 2007, hlm. 5.

9 Hans Kelsen, 1945, General Theory of Law and State, Russell \& Russell, New York, hlm. 35.

${ }^{10}$ Atamimi, A, Hamid S, "Peranan Keputusan Presiden Republik Indonesia dalam Penyelenggaraan Pemerintahan Negara", Suatu Studi Analisis Mengenai Keputusan Presiden yang Berfungsi Pengaturan dalam Kurun Waktu Pelita I-Pelita IV, Disertai Ilmu Hukum Fakultas Pascasarjana Universitas Indonesia, Jakarta, 1990, hlm. 287.
} 
b. Staatsgrundgesetz: Batang Tubuh UUD 1945, Tap MPR, dan Konvensi

Ketatanegaraan.

c. Formell gesetz : Undang-Undang

d. Verordnung en Autonome Satzung: Secara hierarki mulai dari Peraturan Pemerintah hingga Keputusan Bupati dan Walikota.

Sedangkan dalam Pasal 7 Undang-undang Nomor 12 Tahun 2011 tentang Pembentukan Peraturan Perundang-undangan, dalam Pasal 7 menyebutkan jenis dan hierarki Peraturan Perundang-undangan terdiri atas: Undang-Undang Dasar Negara Republik Indonesia tahun 1945; Ketetapan Mejelis Permusyawaratan Rakyat; UndangUndang/Peraturan Pemerintah Pengganti Undang-Undang; Peraturan Pemerintah; Peraturan Presiden; Peraturan Daerah Provinsi; dan Peraturan Daerah Kabupaten/Kota.

\section{Teori Nilai Guna / Utilitas}

Meningkatnya hasil guna dalam penggunaan pemanfaatan parkir tempat parkir khusus dapat meningkatkan pendapatan daerah apabila dikaitkan dengan teory prof posner mengenai analisis ekonomi hukum yang menghasilkan sesuatu / nilai atau kemanfaatan. Mengenai gagasan economy analysis of law sejatinya terlebih dahulu muncul dan dieksplorasi oleh kalangan utilitarianisme dengan tokohnya Jeremy Bentham dan Johm Stuarth Mill. Teori utilitas ini mengutamakan asas kebergunaan sesuatu, jadi sesuatu (esse) harus memberikan manfaat (nilai utilities) bagi esse yang lain (social welfare) ${ }^{11}$. Dalam perkembangannya setelah dianalisis kembali oleh Ronald Coasei pada tahun 1960 dan Posner, ide analisis ekonomi dalam hukum berkembang mencakup transaction cost of economy, economy institution, dan public choice. Transaction cost of economy berkaitan dengan efisiensi peraturan hukum yang sebagian besar berkenaan dengan hukum privat. Economy Institution berkaitan dengan tindakan manusia termasuk peraturan hukum formal, kebiasaan internal, tradisi dan aturan sosial. Serta Public Choice berkaitan dengan proses memutuskan secara demokratis dengan membertimbangkan metode microeconomy dan perdagangannya ${ }^{12}$.

Efisiensi yang terarah menuju social welfare (prinsip utilitarian) adalah hal yang paling ditekankan oleh Richard A Posner. Ia juga tak henti-hentinya berjuang untuk

\footnotetext{
${ }^{11}$ Erman Radjagukguk, "Filsafat Hukum (Modul Kuliah)", Universitas Indonesia, Jakarta, 2011, hlm. 146.

${ }^{12}$ Ibid.
} 
menciptakan tatanan hakim yang memberikan putusan yang bijak dan adil, Selain itu, prinsip analysis of law yang kemudian masuk dalam ranah hukum menjadi suatu keniscayaan yang makin mendekatkan orang pada suatu teorema klasik bahwa hukum bisa menyejahterakan. (wealth maximization) adalah suatu cita-cita yang menarik, namun tak mudah dilaksanakan. Undang-Undang Dasar Negara Republik Indonesia 1945 (UUD 1945) dengan tegas menyatakan dianutnya paham negara kesejahteraan dalam penyelenggaraan negara sebagai negara hukum yang demokratis. Paham negara kesejahteraan ini memberikan alasan yang kuat bagi negara untuk berperan secara lebih luas guna mewujudkan kemakmuran rakyatnya $^{13}$.

\section{HASIL DAN PEMBAHASAN}

\section{A. Apakah Tempat Khusus Parkir Dapat Ditetapkan Di Kawasan Objek Wisata Kuliner Cimanuk Indramayu Berdasarkan Peraturan Daerah Nomor 16 Tahun 2017 Tentang Penyelenggaraan Perparkiran}

\section{a. Pengaturan Penyelenggara Perparkiran}

Kewenangan penyelenggara parkir Pasal 11 ayat 2 Undang-undang No 14 Tahun 1992 menyebutkan bahwa fasilitas parkir untuk umum dapat diselenggarakan oleh Pemerintah, badan hukum Indonesia, atau warga Negara Indonesia. Penyelenggaraan fasilitas parkir meliputi pembangunan, pengoprasian dan pemeliharaan. Penyelenggaraan fasilitas parkir untuk umum, dapat memungut biaya terhadap penggunaan fasilitas parkir yang diusahakannya. Berbeda dengan ketentuan yang berlaku sebelum ini di dalam Peraturan Pemerintah No. 20 tahun 1997 tentang Retribusi, Retribusi parkir hanya dapat dilakukan di pinggir jalan dan di tempat khusus parkir yang diliki atau dikelola oleh pemerintah daerah sedangkan bagi pelataran/gedung parkir yang dimiliki atau dikelola oleh swasta retribusi parkir tidak dapat dipungut oleh Pemerintah Daerah. Fasiltas parkir untuk umum Fasilitas parkir untuk umum diluar jalan dapat berupa taman parkir dan atau gedung parkir.

Secara garis besar Undang-Undang No. 32 Tahun 2004 Tentang Pemerintahan Daerah mengatur lebih rinci mengenai kewenangan tiap daerah untuk mengurus daerahnya masing-masing. Pemerintah dalam menjalankan wewenangnya dibagi dalam beberapa

\footnotetext{
${ }^{13}$ Muhammad Rustamaji, "Menakar Pengawasan Pemberian Bantuan Hukum Dalam Pandangan Richard A Posner", Jurnal Rechts Vinding Vol. 2 No. 1, 2013, hlm. 101.
} 
bidang dan setiap kegiatannya. Adanya batasan-batasan kewenangan dimaksud dilakukan untuk mencegah terjadinya kerancuan dalam penyelenggaraan pemerintahan dan terjadinya penyalahgunaan wewenang di dalam kubu pemerintahan itu sendiri, yang berdampak sulitnya tercapainya tujuan yang diinginkan.

Dalam rangka mewujudkan kelancaran lalu lintas yakni penyelenggaraan pemerintah khususnya dalam bidang pengelolaan perparkiran, untuk menata sistem perparkiran yang tertib dan nyaman, maka diperlukan sistem pelayanan, pengawasan dan pengendalian penyelenggaraan perparkiran. Salah satu upaya Pemerintah Daerah dalam mewujudkan penyelenggaraan perparkiran yang tertib, lancar dan aman dipandang perlu dilakukan penataan dan pengelolaan perparkiran secara terpadu. Penyelenggaraan perparkiran di Kabupaten Indramayu telah diatur dalam Peraturan Daerah Nomor 16 Tahun 2017 tentang Penyelenggaraan Perparkiran, yakni turunan dari Undang-Undang Nomor 22 Tahun 2009 tentang Lalu Lintas dan Angkutan Jalan.

\section{b. Praktik Penetapan Tempat Khusus Parkir Di Kawasan Objek Wisata Kuliner}

\section{Cimanuk Indramayu}

Berbicara mengenai penyelenggaraan perparkiran Pemerintah Indramayu telah menetapkan Peraturan Daerah Kabupaten Indramayu Nomor 16 Tahun 2017 tentang Penyelenggaraan Perparkiran. Terbentuknya Perda Kabupaten Indramayu Nomor 16 Tahun 2017 tentang Penyelenggaraan Perparkiran, bertujuan untuk mewujudkan penyelenggaraan perparkiran yang aman dan nyaman, mewujudkan tertib berlalu lintas di jalan raya, mengendalikan keberadaan parkir pada fasilitas umum milik pemerintah daerah, menata penyelenggaraan parkir swasta dan meningkatkan kontribusi retribusi parkir terhadap $\mathrm{PAD}^{14}$.

Pasal 11 ayat (1) Perda Kabupaten Indramayu Nomor 16 Tahun 2017 membagi 2 (dua) jenis parkir yaitu parkir di tepi jalan umum dan tempat khusus parkir. Pengertian parkir di tepi jalan umum terdapat pada Pasal 1 angka 19 Perda Kabupaten Indramayu Nomor 16 Tahun 2017 yang menyatakan bahwa tempat parkir di tepi jalan kabupaten yang ditetapkan oleh Bupati sebagai tempat parkir kendaraan. Lebih lanjut pengertian tempat khusus parkir telah diatur pada Pasal 1 angka 20 Perda Kabupaten Indramayu Nomor 16 Tahun 2017 menyatakan bahwa tempat parkir kendaraan beserta fasilitas penunjangnya

\footnotetext{
${ }^{14}$ Pasal 4 Peraturan Daerah Indramayu Nomor 16 Tahun 2017 tentang Penyelenggaraan Perparkiran.
} 
yang dimiliki Pemerintah Daerah yang meliputi gedung parkir, taman parkir dan pelataran atau lingkungan parkir. Jenis parkir tepi jalan umum dan tempat khusus parkir memiliki persamanan dan perbedaan. Persamanaannya yaitu tentang pengelolahan tentang parkir yang dikelola oleh pemerintah daerah yang bekerja sama dengan Dinas Perhubungan, sedangkan perbedaanya dari segi letak dan waktunya.

c. Analisa Terhadap Kasus Penetepan Tempat Khusus Parkir Di Kawasan Objek Wisata Kuliner Cimanuk Indramayu Berdasarkan Peraturan Daerah Kabupaten Indramayu Nomor 16 Tahun 2017 tentang Penyelenggaraan

\section{Perparkiran}

Pada penelitian ini penulis berpendapat bahwa penetapan tempat khusus parkir di kawasan objek wisata kuliner Cimanuk Indramayu telah sesuai dengan Peraturan Daerah Kabupaten Indramayu Nomor 16 Tahun 2017 tentang Penyelenggaraan Perparkiran akan tetapi pada implementasinya dianggap masih kurang maksimal, karena menimbulkan permasalahan dimana kawasan kuliner tersebut merupakan salah satu objek wisata yang berada di Kabupaten Indramayu.

Adanya tempat khusus parkir ini kurang tepat ditetapkan di kawasan objek wisata kuliner Cimanuk, karena menimbulkan pertentangan baik dari pengunjung-pengunjung wisata kuliner Cimanuk maupun masyarakat setempat. Menurut masyarakat sekitar wisata kuliner Cimanuk, penetapan parkir khusus ini lebih tepat ditetapkan di gedung perbelanjaan dan wisata rekreasi. Kawasan objek wisata kuliner Cimanuk lebih tepatnya merupakan tempat wisata yang terbuka dan bersahabat untuk masyarakat dan juga pedagang-pedagang, sehingga menjadikan kawasan kuliner cimanuk ini tetap menjadi tempat yang nyaman dan menyenangkan serta tidak pernah sepi pengunjung.

Oleh karena itu penulis berpendapat bahwa teori yang penulis pakai yaitu teori perundang-undangan bahwa teori pembentukan peraturan perundang-undangan sudah dijalankan sesuai hirarki peraturan perundang-undangan yang berlaku. Seharusnya para pelaku pembuat Perundang-Undangan atau Peraturan Daerah harus memiliki pemahaman tentang teori mengenai pembentukan peraturan perundang-undangan dan harus berdasarkan dinamika masyarakat luas dan segala kompleksitasnya. Berdasarkan Pasal 1 ayat (3) Undang-Undang Dasar Negara Republik Indonesia Tahun 1945 menyatakan bahwasanya Indonesia adalah negara hukum. Artinya bahwa semua tindakan dan perilaku yang kita lakukan akan menimbulkan sebab akibat hukum yang akan ditimbulkan. Negara 
hukum selalu berlakunya tiga prinsip hukum dasar yakni supremasi hukum, kesetaraan dihadapan hukum, dan penegakan hukum tidak bertentangan dengan hukum.

Menurut teori utilitas (nilai guna) yakni teori yang menekankan pada tujuan hukum dalam memberikan kemanfaatan/faedah kepada orang terbanyak dalam masyarakat. Bahwasanya dari penerapan aturan mengenai penerapan parkir di wisata kuliner Cimanuk yang diatur dalam Peraturan Daerah Nomor 16 Tahun 2017 tentang Penyelenggaraan Perparkiran bahwasanya aturan tersebut hanya bermanfaat untuk salah satu pihak yakni Pemerintah Daerah Kabupaten Indramayu yakni adanya tambahan pendapatan daerah yakni dalam retribusi parkir dan peningkatan keamanan di wilayah tersebut dikarenakan keamanan kendaraan yang parkir di wilayah itu masih kurang dan masih banyak kejahatan atau pencurian kendaraan (curanmor) adanya peningkatan tersebut untuk meminimalisir adanya kejahatan pencurian kendaraan yang ada di wilayah kuliner Cimanuk tapi dalam hal ini dari sisi pandang lain juga tidak demikian, karena sebagian masyarakat yang sering mengunjungi wisata kuliner Cimanuk merasa tidak adil mengenai aturan tersebut yang diterapkan oleh pemerintah daerah dikarenakan membebankan biaya parkir yang dikenakan oleh pengunjung.

\section{B. Bagaimana Pengelolaan Tempat Khusus Parkir Di Indramayu Berdasarkan Peraturan Daerah Kabupaten Indramayu Nomor 16 Tahun 2017 Tentang Penyelenggaraan Perparkiran}

a. Syarat Penetapan Tempat Khusus Parkir Berdasarkan Peraturan Daerah Kabupaten Indramayu Nomor 16 Tahun 2017 tentang Penyelenggaraan Perparkiran

Berdasarkan Pasal 44 Undang-Undang Nomor 22 tahun 2009 lalu lintas dan angkutan jalan, menyatakan bahwa Penetapan lokasi dan pembangunan fasilitas parkir untuk umum dilakukan oleh pemerintah daerah dengan memperhatikan rencana umum tata ruang, analisis dampak lalu lintas dan kemudahan bagi pengguna jasa. Penerapan Pelaksaan Peraturan Daerah Nomor 16 Tahun 2017 tentang Penyelenggaraan Perparkiran dilakukan bertujuan untuk mewujudkan penyelenggaraan perparkiran yang aman dan nyaman, mewujudkan tertib berlalu lintas di jalan raya, mengendalikan keberadaan parkir pada fasilitas umum milik pemerintah daerah, menata penyelenggaraan parkir swasta dan meningkatkan kontribusi retribusi parkir terhadap PAD khusnya terkait tempat khusus parkir. Berdasarkan pemaparan tersebut, Kabupaten Indramayu membuat persyaratan 
penyelenggaraan tempat khusus parkir.

Mengenai persyaratan penyelenggaraan tempat khusus parkir telah diatur dalam pada Pasal 22 Peraturan Daerah Kabupaten Indramayu Nomor 16 Tahun 2017 tentang Penyelenggaraan Perparkiran. Hal-hal yang perlu diperhatikan dalam membangun tempat khusus parkir, yang pertama adalah; persyaratan administrasi yang meliputi status hak atas tanah/izin pemanfaatan dan dokumen Analisis Dampak Lalu Lintas ${ }^{15}$. Yang kedua adalah persyaratan teknis yang meliputi rencana tata ruang dan dokumen tata ruang lainnya, kajian teknis dari Dinas Teknis, dapat menjamin keamanan, keselamatan dan kelancaraan lalu lintas, mudah dijangkau oleh pengguna jasa, apabila berupa bangunan gedung parkir wajib memenuhi persyaratan bangunan gedung sesuai peraturan perundang-undangan,apabila berupa taman parkir harus memiliki batas-batas persil sesuai peraturan perundangundangan, pengaturan sirkulasi dan posisi parkir kendaraan yang dinyatakan dengan rambu lalu lintas atau marka jalan, penyediaan fasilitas parkir khusus, memenuhi satuan ruang parkir minimal dan menjaga kelestarian fungsi lingkungan hidup ${ }^{16}$.

Berkaitan dengan penetapan tempat khusus parkir dikawasan kuliner Cimanuk Indramayu penulis berpendapat bahwa telah sesuai dengan persyaratan sebagaimana telah diatur pada Pasal 22 Peraturan Daerah Kabupaten Indramayu Nomor 16 Tahun 2017 tentang Penyelenggaraan Perparkiran. Akan tetapi yang menjadi pertentangan bahwa adanya sistem parkir otomatis di kawasan kuliner Cimanuk tersebut yang menimbulkan ketidaknyamanan pengunjung dikarenakan pengenaan tarif parkir yang dihitung perjamnya sudah tentu memberatkan sebagian masyarakat khususnya dikalangan masyarakat yang ingin menghabiskan waktu di kawasan tersebut. Adanya sistem parkir otomatis dinilai kurang tepat diterapkan di kawasan objek wisata kuliner Cimanuk, karena menimbulkan pertentangan baik dari pengunjung-pengunjung wisata kuliner maupun masyarakat setempat. Menurut masyarakat sekitar wisata kuliner Cimanuk, sistem parkir otomatis ini lebih tepat diterapkan di gedung pusat perbelanjaan (seperti Surya, Yogya, Ria Busana dan lain-lain) dan juga pedagang-pedagang didalamnya, sehingga menjadikan kawasan kuliner Cimanuk ini tetap menjadi tempat yang nyaman dan menyenangkan serta tidak pernah sepi pengunjung.

15 Pasal 22 ayat (2) Peraturan Daerah Kabupaten Indramayu Nomor 16 Tahun 2017 tentang Penyelenggaraan Perparkiran.

16 Pasal 22 ayat (3) Peraturan Daerah Kabupaten Indramayu Nomor 16 Tahun 2017 tentang Penyelenggaraan Perparkiran. 
Peraturan Daerah adalah instrumen aturan yang secara sah diberikan kepada pemerintah daerah dalam menyelenggarakan pemerintahan di daerah. Sejak tahun 1945 hingga sekarang ini telah berlaku beberapa undang-undang yang menjadi dasar hukum penyelenggaraan Pemerintah Daerah dengan menetapkan Perda sebagai salah satu instrumen yuridisnya, mengenai pemberlakuan adanya aturan tentang pemerintah daerah sesuai aturan hirarki perundang-undangan diatur dalam Undang-Undang Nomor 12 Tahun 2011 tentang Pembentukan Peraturan Perundang-Undangan. Pembentukan Peraturan Daerah yang demokratis untuk mewujudkan tatanan kehidupan masyarakat yang berbangsa dan bernegara merupakan bagian dari proses pengambilan keputusan yang bersifat publik. Oleh karena itu penulis berpendapat bahwa tokoh pembuat Peraturan Daerah Kabupaten Indramayu harus memiliki pemahaman tentang teori Pembentukan Undang-Undang dan harus berdasarkan dinamika masyarakat luas dengan segala kompleksitasnya.

\section{b. Prosedur Pengelolaan Tempat Khusus Parkir}

Pengelolaan adalah proses, cara perbuatan mengelola untuk melakukan kegiatan tertentu dengan menggerakkan tenaga orang lain untuk pencapaian tujuan organisasi. Proses ini merupakan serangkaian tindakan yang berjenjang, berlanjut dan berkaitan dilakukan untuk mencapai tujuan yang telah ditetapkan ${ }^{17}$.

Adapun penyelenggaraan tempat parkir di Indramayu dalam hal ini diselenggarakan oleh Pemerintah Daerah meliputi tiga jenis perparkiran yang terdiri dari Tempat Parkir di Jalan Umum, Tempat Parkir Khusus, dan Tempat Parkir Tidak Tetap. Kemudian Pemerintah Daerah Indramayu dapat menunjuk Pihak Ketiga yang berbentuk badan hukum sebagai pengelola, untuk menyelenggarakan parkir pada tempat khusus parkir milik Pemerintah Daerah dengan sistem estimasi potensi pendapatan. Pengelola parkir pada tempat khusus parkir sebagaimana wajib: ${ }^{18}$

1. Bertanggungjawab atas segala kegiatan yang berkaitan dengan penyelenggaraan tempat parkir, termasuk kebersihan, pemeliharaan sarana dan prasarana dan keamanan serta ketertiban tempat parkir;

2. Bertanggungjawab atas keamanan kendaraan dan perlengkapannya;

\footnotetext{
${ }^{17}$ R.Terry, George. Prinsip- Prinsip Manajemen. Jakarta: Bumi Aksara, 2006.

${ }^{18}$ Pasal 24 Peraturan Daerah Kabupaten Indramayu Nomor 16 Tahun 2017 tentang Penyelenggaraan Perparkiran.
} 


\section{TURNATE-ISSN 2723-0147}

3. Memenuhi kewajiban atas Pajak Daerah dan/atau Retribusi Daerah;

4. Mencetak Karcis retribusi parkir di bawah pengawasan Pejabat, dalam hal Pemerintah Daerah tidak menyediakan karcis; dan

5. Memiliki Nomor Pokok Wajib Retribusi Daerah (NPWRD) dan Nomor Pokok Wajib Pajak (NPWP).

\section{PENUTUP}

\section{A. Simpulan}

1. Penyelenggaraan perparkiran di Kabupaten Indramayu telah diatur dalam Peraturan Daerah Kabupaten Indramayu Nomor 16 Tahun 2017 tentang Penyelenggaraan Perparkiran. Menurut Pasal 11 ayat (1) Perda Kabupaten Indramayu Nomor 16 Tahun 2017 membagi 2 (dua) jenis parkir yaitu parkir di tepi jalan umum dan tempat khusus parkir. Penetapan tempat khusus parkir dikawasan objek wisata kuliner Cimanuk Indramayu wajib memenuhi peryaratan penyelenggaraan tempat khusus parkir sebagaimana telah diatur pada Pasal 22 Perda Kabupaten Indramayu Nomor 16 Tahun 2017.

2. Berbicara mengenai peryaratan penyelenggaraan tempat khusus parkir telah diatur dalam Pasal 22 Peraturan Daerah Kabupaten Indramayu Nomor 16 Tahun 2017 tentang Penyelenggaraan Perparkiran. Sedangkan prosedur pengelolaan tempat khusus parkir dalam hal ini diselenggarakan oleh Pemerintah Daerah meliputi tiga jenis perparkiran yang terdiri dari tempat parkir di jalan umum, tempat parkir khusus, dan tempat parkir tidak tetap. Kemudian Pemerintah Daerah Indramayu dapat menunjuk Pihak Ketiga yang berbentuk badan hukum sebagai pengelola, untuk menyelenggarakan parkir pada tempat khusus parkir milik Pemerintah Daerah dengan sistem estimasi potensi pendapatan.

\section{B. Saran}

1. Peraturan penyelenggaraan perparkiran di Indramayu dalam hal ini Dinas Perhubungan Kota Indramayu agar lebih intensif dalam memberikan sosialisasi terhadap masyarakat terkait dengan Peraturan Daerah Kabupaten Indramayu.

2. Selain Dinas Perhubungan Kota Indramayu juga kepada DPRD Kota Indramayu dalam membuat aturan harus berdasarkan pada dinamika masyarakat luas dengan segala kompleksitasnya. 


\section{DAFTAR PUSTAKA}

\section{A. Buku :}

Attamimi Hamis S. Peran Keputusan Presiden Republik Indonesia Dalam Penyelenggaraaan Pemerintahan Negara Studi Analisis Mengenai Keputusan Presiden Yang Berfungsi Pengaturan Dalam Kurun Pelita Ke-1 Pelita Ke-IV, Disertasi Doktoral Hukum Tata Negara, Fakultas Pasca Sarjana, Universitas Indonesia, 1991, Hlm 109.

Bagir Manan. Dasar-Dasar Perundang-Undangan Indonesia, Ind-Hill-Co. Jakarta, 1992

Erman Radjaguguk, Filsafat Hukum (Modul Kuliah). Universitas Indonesia Jakarta, Jakarta, 2011

Hans Kelsen, General Theory of Law and State, Russell \& Ruseell, New York, 1945

M. Solly Lubis, Filsafat Ilmu dan Penelitian, Bandar Maju, Bandung, 1994

Mahendra Kurniawan, dkk, Pedoman Naskah Akademik PERDA Partisipatif, Cet. Ke I, Kreasi Total Media, Yogyakarta, 2007

Moh. Kusnardi, Hukum Tata Negara Indonesia, Sinar Bakti, 1987

Ridwan HR, Hukum Administrasi Negara Indonesia, PT. Raja Grafindo Persada, Jakarta, 2006

R. Terry, George, Prinsip Manajemen, Bumi Aksara, Jakarta, 2006

Rozikin Daman, Hukum Tata Negara, PT. Raja Grafindo Persada, Jakarta

Soerjono Soekanto dan Sri Mamudji, Penelitian Hukum Normatif: Suatu Tinjauan Singkat _Cet.9, Rajawali Press, Jakarta, 2006

Stahl, Julius dalam Jimly Asshidiqque, Konstitusi \& Konstitualisme Indonesia, Cet. 2, Sinar Grafika, Jakarta, 2011

\section{B. Jurnal :}

Muhammad Rustamaji, Menakar Pengawasan Pemberian Bantuan Hukum Dalam Pandangan Richard A Posner, Jurnal Rechts Vinding Vol. 2 No. 1, 2013

\section{Peraturan Perundang-Undangan}

Peraturan Daerah Kabupaten Indramayu Nomor 16 Tahun 2017 tentang Penyelenggaraan Perparkiran. 